\title{
Women and Money: Unique Issues - Money Issues Across the Life Cycle ${ }^{1}$
}

\author{
Diann Douglas, Martie Gillen, and Lynda Spence ${ }^{2}$
}

Societal dynamics and their effects on gender roles and family structures underscore a distinct need for financial management education to address the unique issues that women may encounter. This series of EDIS publications, "Women and Money: Unique Issues," encompasses financial management for women across the life cycle and through family transitions. This series focuses on the changes women may encounter throughout their lives and the impact of these changes on their economic status. For the rest of the publications in the series, see http://edis.ifas. ufl.edu/topic_series_women_and_money_unique_issues.

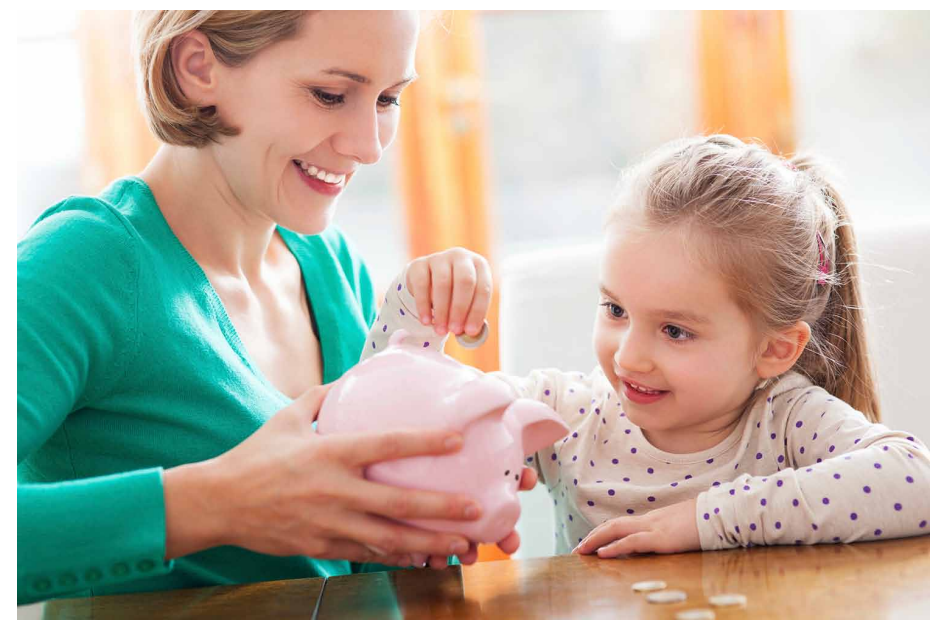

Figure 1. Women often encounter situations in life unique to them that can affect their financial status.

Credits: iStockphoto

\section{Introduction}

Most families depend on a woman's income to help support the household. Some women are co-breadwinners while others are the only source of income. Throughout a woman's life, she will experience many money issues unique to women. A woman may experience the following situations: lower earnings, a longer life expectancy, lack of retirement planning, divorce, and fewer years in the workplace because of childrearing or caring for older parents. Many of these issues can work against a woman's ability to accumulate money and attain stable financial status.

\section{Lower Lifetime Earnings}

As a population, women generally earn a lower income than their male counterparts. The Equal Pay Act that passed in the 1960s was supposed to narrow the earning gap between men and women, yet a gender pay gap still exists today. Even after accounting for possible explanations such as demographic characteristics, family situations, work hours, and work experience, women who work full-time year-round still are paid $77 \%$ of a man's pay $(\$ 37,000$ for a woman compared to $\$ 48,000$ for a man in 2009) (U.S. Census Bureau 2012).

After a woman has accumulated years in the workplace, it seems that the wage gap would shrink because of experience. This, however, is not the case. Inequities start early

1. This document is FCS7248, one of a series of the Department of Family, Youth, and Community Sciences, UF/IFAS Extension. Original publication date: March 2013. Please visit the EDIS website at http://edis.ifas.ufl.edu.

2. Diann Douglas, County Extension director and Extension agent IV, UF/IFAS Extension Madison County; Martie Gillen, assistant professor and Family and Consumer Economics for Older Adults specialist, Department of Family, Youth and Community Sciences; and Lynda Spence, Extension agent I, UF/IFAS Extension Marion County; UF/IFAS Extension, Gainesville, FL 32611.

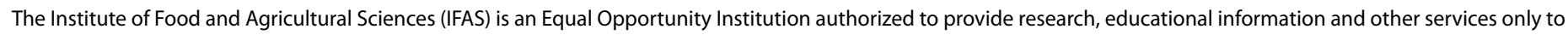

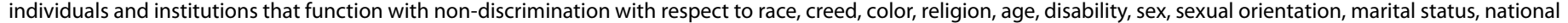
origin, political opinions or affiliations. U.S. Department of Agriculture, Cooperative Extension Service, University of Florida, IFAS, Florida A\&M University Cooperative Extension Program, and Boards of County Commissioners Cooperating. Nick T. Place, Dean 
and worsen over time. Research has shown a 5\% difference one year after college graduation and a $12 \%$ difference after 10 years. The only identified explanation for the unexplained gaps was gender discrimination (Arnst 2007; Boushey, Aarons, and Smith 2010).

Glaring differences exist even within professional occupations. The Bureau of Labor Statistics (2011) revealed the largest gender wage gaps were in four occupations: physicians, financial services, financial manager, and business operations specialist.

\section{Longer Life Expectancy}

Women tend to live longer than men. Women have an average life expectancy of 81 years compared to 76 years for men (U.S. Department of Health and Human Services 2011). This means that on average a woman will need more funds in retirement.

\section{Breaks in Career}

Women are more likely to have gaps in their work years because of childrearing (Duke 2010). Some women may leave their jobs for extended periods of time to go on maternity leave. Other women make the choice to stay home for an extended time, reentering the job market years later. During childrearing years, some women may leave careers behind and choose to work part-time or find a job with hours that match closely with children's school schedules.

These changes may prevent women from investing in retirement plans and may reduce the total number of years a woman is in the workplace contributing to Social Security benefits. As a result, upon retirement age, women's income and Social Security benefits are often lower than those of their male counterparts.

Women need to pay attention to any employer retirement plan or matched contributions that may have been a job benefit. Find out about retirement or savings before you leave the job. If money is invested in a retirement plan, can it stay until you are ready to retire? What are the options?

Before leaving a job, if retirement was a benefit, the Social Security administration recommends you get copies of the company's summary plan description (SPD) and any amendments. This will detail possible benefit reductions due to early retirement.

If you are entitled to a lump sum, consider rolling the funds into an Individual Retirement Account (IRA). This should avoid tax penalties and allows the money to continue in an account for your long-term retirement.

For more information on handling your money while raising a family, see another publication in this series, FY1354/ FCS7250 Women and Money: Unique Issues - Money and the Family (http://edis.ifas.ufl.edu/fy1354).

\section{Divorce}

The divorce rate in the United States is estimated at $36 \%-50 \%$ (U.S. Census Bureau 2010). In general, divorce creates a financial disaster for families and may leave a woman to raise children using less money. Even if child support is paid on a regular basis, it doesn't make up for the reduction in total household income. Many female-headed households struggle to pay the bills because of a sudden drop in income.

Spending may likely need to change when a divorce occurs. Review monthly expenditures and establish a budget. Since cash flow may drastically change and not be the same from week to week, continue to review income and expenses.

Depending on the number of years a woman was married, she may be entitled to part of her husband's retirement income. Be sure all financial issues are revealed and resolved during divorce proceedings.

For more information on financial issues during a divorce, see another publication in this series FY1349/FCS7247 Women and Money: Unique Issues - Finances in a Divorce (http://edis.ifas.ufl.edu/fy1349).

\section{Care of Elderly Parents}

Another family obligation that may interfere with building wealth is caring for an elderly or ailing parent or other family member. Often women tend to be the major caregivers for sick or older parents. Some women may take a career break or retire early to attend to the full-time care of a family member. Even if a woman continues to work, caring for the family member may become a financial burden. Often there is a reduction of income and less money to contribute to retirement.

\section{Widowhood}

As women age, the likelihood of living alone increases. Women live longer than men and are thus more likely to outlive their spouses. According to the U.S. Census Bureau (2010), among those 65 and older, $44 \%$ of women were married, compared to $75 \%$ of men. Widowed women 
account for approximately $40 \%$ of women 65 and older, but only $13 \%$ of men 65 and older are widowed (U.S. Census Bureau 2010). The average age of widowhood is 55 years old (U.S. Census Bureau 2010).

A spouse's death is not only emotionally draining but also will likely have financial consequences (e.g., loss of income from pension or Social Security retirement benefits).

\section{Lack of Retirement Planning}

As a whole, women tend to focus less on planning for their retirement over the course of their career, having saved less for retirement than men (Institute for Women's Policy Research 2012). Because women are often the caregivers for the family, taking steps to ensure their financial future may take a backseat when other events occur.

In general, women are not risk takers (Edward Jones 2012). When women do put money into a retirement fund, it is often a conservative investment that earns lower interest rates than their male counterparts. Women also may not research investments to identify the best options, nor do they keep up with market changes to diversify retirement investments.

\section{Take Action}

In spite of the issues women face with less income and retirement benefits, women can take steps to improve their financial status and retirement income. Financial planning and learning about investing are the first steps on the road to financial independence. Time is on your side when you start early. Small amounts of money saved and invested over time add up to a secure financial life.

\section{References}

Arnst, C. 2007. "Women and the Pay Gap." Bloomberg Businessweek. Accessed February 2013. http://www.businessweek.com/stories/2007-04-26/women-and-the-pay-gap.

Boushey, H., J. Aarons, and L. Smith. 2010. "Families Can't Afford the Gender Wage Gap." Center for American Progress. Accessed February 2013. http://www.americanprogress.org/wp-content/uploads/issues/2010/04/pdf/ equal_pay_day.pdf.

Bureau of Labor Statistics. 2011. Household Data Annual Averages: Median Weekly Earnings of Full-time Wage and Salary Workers by Detailed Occupation and Sex. Accessed February 2013. http://www.bls.gov/cps/cpsaat39.pdf.
Duke, M. 2010. Women and Money: Challenging the Myths. Remarks to the Board of Governors of the Federal Reserve System. Accessed February 2013. http://www.federalreserve.gov/newsevents/speech/duke20100501a.pdf.

Edward Jones. 2012. A Woman's Guide to Money Matters. St. Louis: Edward Jones.

Institute for Women's Policy Research. 2012. Talking Points on Retirement and Social Security. Accessed February 2013. http://www.iwpr.org/publications/pubs/ talking-points-on-retirement-and-social-security.

U.S. Census Bureau. 2010. "Table 126. Marriages and Divorces - Number and Rate by State: 1990 to 2007." Statistical Abstract of the United States 2010. Accessed February 2013. http://www.census.gov/compendia/statab/2010/ tables/10s0126.pdf.

U.S. Census Bureau. 2012. Educational Attainment in the United States: 2009. Accessed February 2013. http://www. census.gov/prod/2012pubs/p20-566.pdf.

U.S. Department of Health and Human Services. 2011. Health, United States, 2011. Accessed February 2013. http:// www.cdc.gov/nchs/data/hus/hus11.pdf\#021. 